\title{
P64. T cell re-direction against Glypican-3 for immunotherapy of hepatocellular carcinoma
}

\author{
C Dargel $^{l^{*}, \text { M Bassani-Sternberg }}{ }^{2}$, K Krebs $^{1}$, S Wilde $^{3}$, D Schendel $^{3}$, DH Busch $^{4}$, M Mann $^{2}$, U Protzer $^{1}$ \\ From 1st Immunotherapy of Cancer Conference (ITOC1) \\ Munich, Germany. 12-14 March 2014
}

Hepatocellular carcinoma (HCC) is the third most common cause of cancer related mortality world-wide and therapeutic options are very limited. A new therapeutic approach is the adoptive T cell therapy of HCC. Glypican-3 (GPC3) as a tumour associated antigen is expressed in up to $60 \%$ of all HCC but not in healthy human liver tissue. Therefore, our goal is to generate cytotoxic $\mathrm{T}$ lymphocytes (CTL), which are capable of recognizing and eliminating GPC3-expressing tumor cells.

Immunodominant epitopes for GPC3 have not been described yet. In this study we used Ultra Nano HPLC coupled on-line to the Q Exactive mass spectrometer to obtain a comprehensive HLA class I peptidome from a GPC3 and HLA-A2 positive hepatoma cell line. The resulting data were analysed using the MaxQuant bioinformatics platform. Two HLA-A2 bound GPC3 peptides could be identified, later on referred to as GPC3-P1 and GPC3-P2. These results enable us to target GPC3 epitopes that are presented on GPC3 positive HCC cells.

To isolate tumour reactive high avidity $\mathrm{T}$ cells, an allorestricted stimulation approach was used. For stimulation of naïve $\mathrm{T}$ cells, autologous dendritic cells were co-transfected with GPC3 and HLA-A2 RNA and used as antigen presenting cells. $T$ cells from the naïve $T$ cell repertoire of HLA-A2 negative donors were co-cultured with and expanded on these HLA-A2+ GPC3+ DCs. After two weeks, MHC streptamer-positive $\mathrm{CD}^{+} \mathrm{T}$ cells specific for both targeted GPC3 epitopes were detected $(<1 \%)$. We were able to enrich these cell populations further to 35\% GPC3-P1- and 57\% GPC3-P2-MHC streptamer-positive T cell lines and grew $\mathrm{T}$ cell clones from them. In a co-culture with GPC3$\mathrm{P} 1 /$-P2 peptide loaded T2 cells we identified T cell clones displaying specific effector function by IFN $\gamma$ secretion. Functional T cell clones showed strong GPC3 MHC streptamer binding.

${ }^{1}$ Institute of Virology, Technische Universität, München, Germany Full list of author information is available at the end of the article
We have cloned the first $\mathrm{T}$ cell receptors (TCR) to either GPC3 peptide from these $T$ cell clones. T cells engrafted with the GPC3 specific TCRs showed strong GPC3 MHC streptamer binding. When co-cultured with GPC3 peptide loaded target cells or a GPC3 expressing hepatoma cell line (HepG2), GPC3 TCR transduced T cells secreted IFN $\gamma$. Furthermore cytotoxicity was observed by killing of up to $60 \%$ of HepG2 cells. GPC3-directed T cell therapy shows great promise for the treatment of HCC.

\section{Authors' details}

${ }^{1}$ Institute of Virology, Technische Universität, München, Germany. ${ }^{2}$ Institute of Biochemistry, Max-Plank-Institute, München, Germany. ${ }^{3}$ Institute of Molecular Immunology, Helmholtz Zentrum, München, Germany. ${ }^{4}$ Institute for Medical Microbiology Immunology and Hygiene, Technische Universität, München, Germany.

Published: 12 March 2014

doi:10.1186/2051-1426-2-S2-P38

Cite this article as: Dargel et al:: P64. T cell re-direction against

Glypican-3 for immunotherapy of hepatocellular carcinoma. Journal for ImmunoTherapy of Cancer 2014 2(Suppl 2):P38.

Submit your next manuscript to BioMed Central and take full advantage of:

- Convenient online submission

- Thorough peer review

- No space constraints or color figure charges

- Immediate publication on acceptance

- Inclusion in PubMed, CAS, Scopus and Google Scholar

- Research which is freely available for redistribution 